\title{
Toxicity effects of nickel electroplating effluents treated by photoelectrooxidation in the industries of the Sinos River Basin
}

\author{
Benvenuti, T. ${ }^{a *}$, Rodrigues, MAS. ${ }^{b}$, Arenzon, A. ${ }^{c}$, Bernardes, AM. ${ }^{a}$ and Zoppas-Ferreira, J. $^{a}$ \\ ${ }^{a}$ Laboratório de Corrosão, Proteção e Reciclagem de Materiais, Programa de Pós-Graduação em Engenharia de Minas, \\ Metalúrgica e de Materiais - PPGEM, Universidade Federal do Rio Grande do Sul - UFRGS, Avenida Bento Gonçalves, \\ 9500, Agronomia, CEP 91501-970, Porto Alegre, RS, Brazil \\ bPrograma de Pós-Graduação em Qualidade Ambiental, Universidade Feevale, \\ Rodovia RS 239, 2755, CEP 93352-000, Novo Hamburgo, RS, Brazil \\ 'Laboratório de Ecotoxicologia, Centro de Ecologia, Universidade Federal do Rio Grande do Sul - UFRGS, \\ Avenida Bento Gonçalves, 9500, Agronomia, CEP 91501-970, Porto Alegre, RS, Brazil \\ *e-mail: benvenuti.tatiane@gmail.com
}

Received: May 24, 2013 - Accepted: July 24, 2013 - Distributed: May 31, 2015

(With 6 figures)

\begin{abstract}
The Sinos river Basin is an industrial region with many tanneries and electroplating plants in southern Brazil. The wastewater generated by electroplating contains high loads of salts and metals that have to be treated before discharge. After conventional treatment, this study applied an advanced oxidative process to degrade organic additives in the electroplating bright nickel baths effluent. Synthetic rinsing water was submitted to physical-chemical coagulation for nickel removal. The sample was submitted to ecotoxicity tests, and the effluent was treated by photoelectrooxidation (PEO). The effects of current density and treatment time were evaluated. The concentration of total organic carbon (TOC) was $38 \%$ lower. The toxicity tests of the effluent treated using PEO revealed that the organic additives were partially degraded and the concentration that is toxic for test organisms was reduced.
\end{abstract}

Keywords: nickel plating effluent, organic additives, photoelectrooxidation, toxicity.

\section{Avaliação do efeito tóxico de efluentes oriundos da indústria galvânica na região da Bacia do Rio dos Sinos após o tratamento pelo processo de fotoeletrooxidação}

\begin{abstract}
Resumo
A Bacia do Rio dos Sinos é uma região do Sul do Brasil que sedia um importante pólo da indústria coureiro-calçadista incluindo, desde o beneficiamento das peles, em curtumes, à fabricação dos acessórios, em indústrias metalúrgicas e de galvanoplastia. O efluente gerado por processos galvânicos contém carga elevada de sais e metais que devem ser tratados antes do descarte. Neste artigo foi avaliada a aplicação de um processo oxidativo avançado após o tratamento convencional do efluente, visando degradar os aditivos orgânicos presentes nos efluentes dos banhos de eletrodeposição de níquel brilhante. Um efluente sintético foi tratado pelo processo físico-químico de coagulação para a remoção do níquel. A amostra foi, então, submetida a testes de ecotoxicidade e, em seguida, o efluente foi tratado pelo processo de fotoeletrooxidação (FEO). A influência da densidade de corrente e o tempo de tratamento foram avaliados. Foi verificada uma redução de carbono orgânico total superior a $38 \%$. Os ensaios de ecotoxicidade para o efluente tratado por fotoeletroxidação indicaram que a FEO degradou parcialmente os aditivos orgânicos e reduziu a concentração que provoca efeitos tóxicos para os organismos teste.
\end{abstract}

Palavras-chave: efluentes de níquel, aditivos orgânicos, fotoeletrooxidação, toxicidade.

\section{Introduction}

Brazil has a privileged position in availability of water resources in the world. The hydrographical region of South Atlantic is located in the state of Rio Grande do Sul, where this study was conducted. Water resources in this region are divided into $14 \%$ for urban uses, $12 \%$ for industrial use, $1 \%$ for rural proposes, $71 \%$ for irrigation and $2 \%$ for animals. The urban rate of water treatment is $90 \%$, and the sewage treatment rate is $27 \%$ (Brasil, 2007). The Atlântico Sul region includes different hydrographical basins, one of which is the Sinos River basin, which is 
in an area with 1.6 million inhabitants. In the basin area, there are 650 factories and plants, 198 of which are metallurgical plants. Of the 100 factories with the highest pollution potential in the state of Rio Grande do Sul, 29 are located in the area of the Sinos River basin. Industrial effluents account for $19 \%$ of the wastewater discharge in this basin, and the rate of urban sewage discharge is also high (Rio Grande do Sul, 2001).

To improve the conditions of the Sinos River, wastewater of metallurgical plants should be efficiently treated. Presently, there is no conventional effluent treatment to obtain water that can be reused in the same process. Before discharge, galvanic and other industrial effluents must be evaluated for ecotoxicity, which should ensure that the effluent does not have toxic effects (CONSEMA, RS 129/2006). This study evaluated the photoelectrooxidation (PEO) treatment of nickel electroplating effluents.

As several other electroplated metals, nickel is widely used because it improves resistance to corrosion and provides decorative finishing (Schario, 2007). The Watts bath, composed of $\mathrm{NiCl}_{2}, \mathrm{Ni}_{2} \mathrm{SO}_{4}$ and $\mathrm{H}_{3} \mathrm{BO}_{3}$, is the most widely used process. For brightness coatings, organic additives are added to the bath (Ciszewski et al., 2004). Therefore, electroplating generates large amounts of wastewater with nickel and organic compounds.

Different processes are used to treat these effluents: coagulation-flocculation, flotation, ion exchange, adsorption, electrocoagulation, electrolysis and membrane processes, such as electrodialysis, reverse osmosis and micro-, nano- and ultra-filtration. Metal removal rates are greater than $99 \%$, but vary for each metal and process. However, organic additives are molecules that may persist after conventional treatment, which makes removal difficult and expensive (Fu and Wang, 2011).

Few studies investigated the degradation of organic pollutants in wastewaters containing metals, because these organic molecules often act as chelating agents that can form stable and water-soluble complexes with many metal ions (Maszenan et al., 2011); biodegradation becomes difficult (Venugopalan et al., 2005) and electrodeposition is not an economically viable technique for treatment (Allen and Chen, 1993; Campbell et al., 1994).

Different advanced oxidative processes (AOPs) have been used to degrade organic pollutants in wastewaters: photoelectrochemical, electrochemical, UV-photooxidation, $\mathrm{UV}, \mathrm{H}_{2} \mathrm{O}_{2}, \mathrm{O}_{3}$, ultrasound, Fenton and combined processes (Kang et al., 2001; Manu and Mahamood, 2011; Yan-yang et al., 2011). AOPs are characterised by the generation of hydroxyl radicals $(\bullet \mathrm{OH})$, which have a high potential for compound oxidation $(2.8 \mathrm{~V})$, and the role of AOPs is to enable the complete mineralisation of organic pollutants into $\mathrm{CO}_{2}$, water, and mineral acids.

This study used photoelectrooxidation (PEO), which includes two simultaneous processes: electrolysis and heterogeneous photocatalysis. PEO is a mediated reaction and occurs via oxygen atom transfer from water in the solvent phase to the oxidation product. A solution passes through an electrolytic reactor where the anode is under UV radiation (Rodrigues et al., 2008).

Many studies have focused on effluent toxicity after treatment with AOPs. The major concern when using AOPs is the incomplete oxidation of organic compounds in the solution, which form toxic intermediates that can reduce biodegradability (Lu et al., 2011).

The novelty of this paper is the application of the PEO treatment to degrade organic additives in rinsewaters of Watts nickel electroplating baths. Our purpose was to evaluate the degradation of organic additives when using PEO and the toxicity of the treated effluent. The removal of these organic additives from effluents before their discharge into rivers may contribute to the reduction of pollution of water resources.

\section{Material and Methods}

Experiments were carried out according to Figure 1a.

\subsection{Solutions}

Two nickel bath samples were prepared with commercial products in the concentrations used in the electroplating industry for nickel plating, according to Table 1: B is the

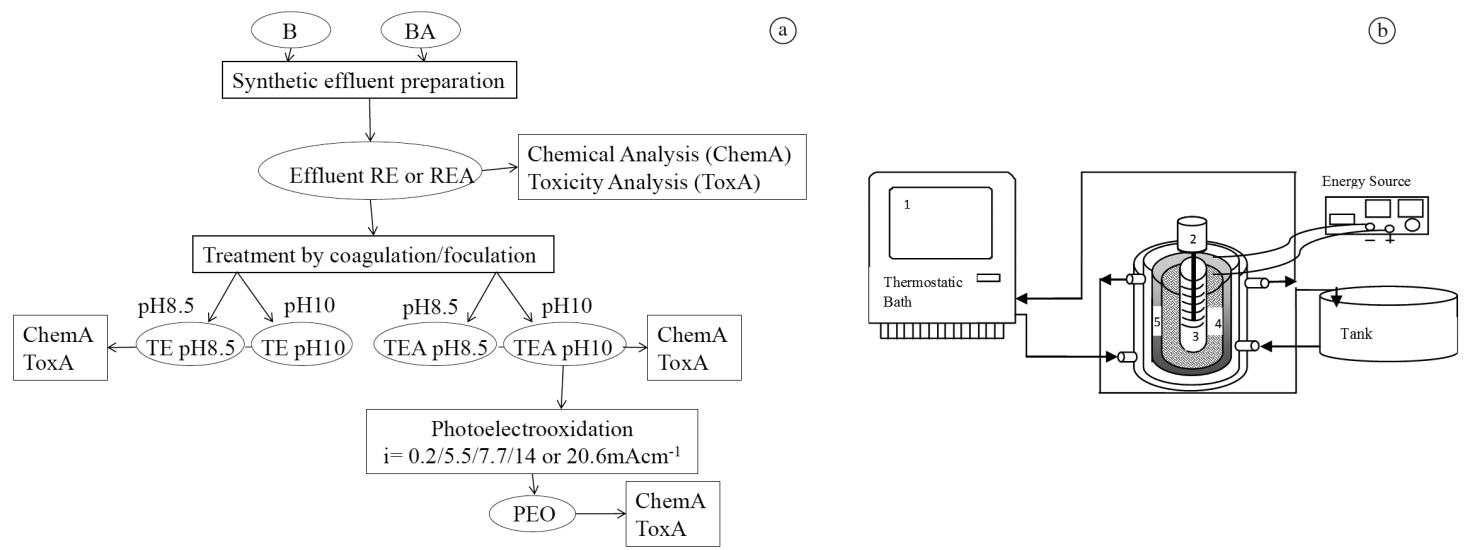

Figure 1. Methods (a) Schematic representation of method used in this study. (b) Photoelectrooxidation system: [1] Thermostatic bath; [2] $250 \mathrm{~W}$ mercury vapor lamp; [3] Quartz tube; [4] Ti/Ru Anode; [5] Stainless steel cathode. 
Table 1. Synthetic solutions for nickel plating baths without (B) or with (BA) additives.

\begin{tabular}{|c|c|c|}
\hline Components & B & BA \\
\hline $\mathrm{NiCl}_{2}$ & 65 g.L. ${ }^{-1}$ & 65 g. $\mathrm{L}^{-1}$ \\
\hline $\mathrm{NiSO}_{4}$ & 275 g... ${ }^{-1}$ & 275 g. $\mathrm{L}^{-1}$ \\
\hline $\mathrm{H}_{3} \mathrm{BO}_{3}$ & 45 g... ${ }^{-1}$ & 45 g.L $\mathrm{L}^{-1}$ \\
\hline Abr50 $1^{\circledR}$ (brightener) & - & $20 \mathrm{~mL} \cdot \mathrm{L}^{-1}$ \\
\hline 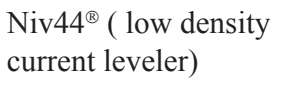 & - & $20 \mathrm{~mL} . \mathrm{L}^{-1}$ \\
\hline $\begin{array}{l}\text { Niv55 }{ }^{\circledR} \text { (high current } \\
\text { density leveler) }\end{array}$ & - & $20 \mathrm{~mL} . \mathrm{L}^{-1}$ \\
\hline $\mathrm{MolC}^{\circledR}$ (surfactant) & - & $5 \mathrm{~mL} . \mathrm{L}^{-1}$ \\
\hline
\end{tabular}

nickel bath and $\mathrm{BA}$, the nickel bath containing organic additives. From solutions B and BA, dilutions were prepared with $10 \mathrm{~mL}$ of bath in $1 \mathrm{~L}$ of distilled water to obtain the synthetic effluents.

Synthetic effluents were grouped according to the presence of organic additives and the type of treatment, as shown in Figure 1a. The conventional physical-chemical treatment in the metal finishing industry was used for raw effluents (RE and REA): nickel precipitation was performed using $50 \% \mathrm{NaOH}$, followed by flocculation with the anionic polymer Masfloc $\mathrm{AF}^{\circledR}(0.1 \%)$. RE and REA pH was about 5; pH 8.5 and 10 were used for the treatment and generated TE and TEA. After treatment, the effluents were filtered using $140-\mu \mathrm{m}$ filter paper.

\subsection{Experimental apparatus}

The experimental system is shown in Figure $1 \mathrm{~b}$. The PEO reactor had a volume of $1.6 \mathrm{~L}$. It was built with borosilicate glass, recirculation of the effluent to be treated and a temperature control system coupled with a thermostatic bath [1]. During the experiments, the temperature was kept at $30^{\circ} \mathrm{C}$. The light source was a mercury vapor lamp of $250 \mathrm{~W}$ [2] whose bulb was removed and replaced with a quartz tube measuring $5 \mathrm{~cm}$ in diameter [3]. The lamp was turned on 15 minutes before the test started to ensure the stabilization of the radiation. The DeNora DSA ${ }^{\circledR}$ electrode (Brazil) [4] was a $437 \mathrm{~cm}^{2}$ titanium plate coated with metal oxides $\left(70 \% \mathrm{TiO}_{2} / 30 \% \mathrm{RuO}_{2}\right)$ and placed around the quartz tube, which therefore remained under UV radiation. At a distance of $1 \mathrm{~cm}$ from the anode, a stainless steel AISI420 cylinder was used as the cathode [5]. A volume of $2.5 \mathrm{~L}$ of effluent was fed into the tank and the reactor at an average flow of $1 \mathrm{Lmin}^{-1}$, using a centrifugal pump. The PEO electrodes were cleaned using a sulfuric acid solution at $\mathrm{pH} 1$ by applying a current density of $6.9 \mathrm{~mA} . \mathrm{cm}^{-2}$ for 15 min between each test.

The current density evaluated in the PEO1 test was determined according to cyclic voltammetry studies for effluents and $\mathrm{Ti} / \mathrm{TiO}_{2} \mathrm{RuO}_{2}$ anode (Benvenuti et al., 2011). Five PEO experiments were performed in duplicate for 60 minutes to assess current density (i) effect using $\mathrm{PEO} 1=0.2 \mathrm{mAcm}^{-2} ; \mathrm{PEO} 2=5.5 \mathrm{mAcm}^{-2} ; \mathrm{PEO} 3=7.7 \mathrm{mAcm}^{-2}$; $\mathrm{PEO} 4=14 \mathrm{mAcm}^{-2}$ and PEO5 $=20.6 \mathrm{mAcm}^{-2}$. The effect of the treatment time was evaluated for PEO1 and PEO3 tests for 120 and 180 minutes.

\subsection{Analytical measurements}

The effluents (RE, REA, TE, TEA) were characterized according to nickel concentrations by flame atomic absorption spectrophotometry (Varian - FS 240). The analysis of inorganic (IC), organic (TOC) and total (TC) carbon were performed using the Shimadzu TOCV CSH. A UV/V molecular absorption spectrometer (T80-PG Instruments) was used for UV analysis.

\subsection{Toxicity}

The ecotoxicity tests for RE, REA, TE and TEA effluents and the final sample PEO3 test were performed according to the Brazilian Association of Technical Standards (ABNT). The acute toxicity to Daphnia magna (Straus 1820) microcrustacean was evaluated using the NBR 12713:2009 standard (ABNT, 2009), based on ASTM E1193-97 (ASTM, 1987). Acute toxicity to Pimephales promelas (Rafinesque 1820) fish was evaluated using tests defined in the NBR 15088:2004 standard (ABNT, 2004), similar to the USEPA Method 2000.0 (United States of American, 2002a). Toxicity tests for Selenastrum capricornutum algae (Printz 1914) were performed according to NBR 12648:2005 standard ABNT, 2005), which is similar to the USEPA method 1003.0 (United States of American, 2002b).

\section{Results and Discussion}

\subsection{Physic-chemical characterization}

Figure 2a describes the results of the analysis of total organic carbon (TOC), inorganic carbon (IC) and total carbon (TC) for all effluents. The effect of the organic additives was seen in the REA effluent, in which TOC was $50 \mathrm{mgL}^{-1}$, while TOC in the RE effluent was almost zero. There was an increase in IC, TC and TOC concentrations in the TEApH8,5, TEApH10 and TEpH10 samples, which demonstrated the addition of the polymer effect to the effluent treatment and primarily contributed to an increase of the inorganic filler.

Table 2 shows a high concentration of $\mathrm{Ni}$ in raw effluent samples (REA, RE). After the physical-chemical treatment, there was a higher efficiency of conventional treatment with an increase of $\mathrm{pH}$ from 8.5 to 10 . The percentage removal was calculated using Equation1, where initial $\left([\mathrm{Ni}]_{0}\right)$ and final $\left([\mathrm{Ni}]_{\mathrm{f}}\right)$ nickel concentrations were used:

$E p \%=\left(\left([N i]_{0}-[N i]_{f}\right) /[N i]_{0}\right) * 100$

Even with efficiency greater than $99 \%$ for the treatments carried out at $\mathrm{pH} 10$, the concentrations found after treatment confirm the difficulty of the final effluent to meet the standards set by law for effluent disposal (CONAMA 357 (BRASIL, 2005) and CONSEMA 128, (Rio Grande do Sul, 2006)). The biological effects of the organic and inorganic pollutants together in the effluent cannot be assessed using only traditional physical-chemical analyses; therefore, the samples were tested for toxicity. 


\subsection{Toxicity tests}

In the raw effluents under evaluation (RE and REA), the interaction between the test organisms and high nickel concentrations had a predominant effect on the comparison between samples with and without additives, as shown in Table 3. According to Table 2, RE and REA did not reach the physical and chemical parameters for disposal, and $\mathrm{pH}$ was around 5. Besides that, a high Ni concentration gave the effluent the high toxicity observed for the three trophic levels. For TEpH10 and TEApH10, more than $99 \%$ of Ni was removed, and the $\mathrm{pH}$, corrected after treatment to the acceptable range for disposal, was close to 7. Increases in concentrations that cause acute effects were observed for all three levels, but were far from $100 \%$ concentration, which indicates that the effluent without dilution might house the test organisms without mortality, immobility, or growth population inhibition.

The algae were the most sensitive to the tested samples (Table 3); they had more critical inhibition concentrations.

Table 2. Variations in the nickel concentration and percentage of removal after physical-chemical treatment (FAAS analysis).

\begin{tabular}{lccccc}
\hline \multicolumn{1}{c}{ Sample } & {$[\mathbf{N i}] \mathbf{m g L}^{-\mathbf{1}}$} & Mean & SD & Ep\% & Limit for discharge \\
\hline RE & 1137.3 & - & - & & CONAMA 357/2005 \\
TEpH8.5 & 152.9 & 130.7 & 22.5 & 86.55 & $2 \mathrm{mgL}^{-1}$ \\
TEpH10 & 4.3 & 5.86 & 2.2 & 99.48 & \\
REA & 1024.7 & - & - & & CONSEMA128/2006 \\
TEApH8.5 & 127.2 & 90.64 & 51.68 & 91.16 & $1 \mathrm{mgL}^{-1}$ \\
TEApH10 & 1.32 & 3.78 & 4.66 & 99.63 & \\
\hline
\end{tabular}

Mean: the average concentration of three samples were calculated. SD: the standard deviation between the nickel concentration analysed for the samples. Ep\%: percentage extraction of nickel calculated after the physico-chemical treatment.

Table 3. Ecotoxicological characterisation of raw and treated effluents.

\begin{tabular}{|c|c|c|c|}
\hline Sample & $\begin{array}{c}\text { Acute toxicity for } \\
\text { Pimephales promelas } \\
\text { LC(I)50 }{ }^{\mathrm{a}}, 48 \mathrm{~h} \\
\end{array}$ & $\begin{array}{l}\text { Acute toxicity for } \\
\text { Daphnia magna } \\
\text { EC(I)50 } 5^{\text {b }}, 48 \mathrm{~h}\end{array}$ & $\begin{array}{c}\text { Acute toxicity for } \\
\text { Selenastrum capricornutum } \\
\text { IC(I)50c, 72h }\end{array}$ \\
\hline $\mathrm{RE}$ & $0.40 \%$ & $0.59 \%$ & $0.0083 \%$ \\
\hline TEpH10 & $70.71 \%$ & $72.01 \%$ & $5.23 \%$ \\
\hline REA & $0.40 \%$ & $0.66 \%$ & $0.0116 \%$ \\
\hline TEApH10 & $70.71 \%$ & $70.71 \%$ & $4.57 \%$ \\
\hline
\end{tabular}

${ }^{\mathrm{a}} \mathrm{LC}(\mathrm{I}) 50$ : concentration of sample that kills $50 \%$ of the organisms. ${ }^{\mathrm{b}} \mathrm{EC}(\mathrm{I}) 50$ : concentration of sample that immobilizes $50 \%$ of the organisms. ${ }^{\mathrm{c}} \mathrm{IC}(\mathrm{I}) 50$ : concentration of sample that inhibits growth of $50 \%$ of the organisms.
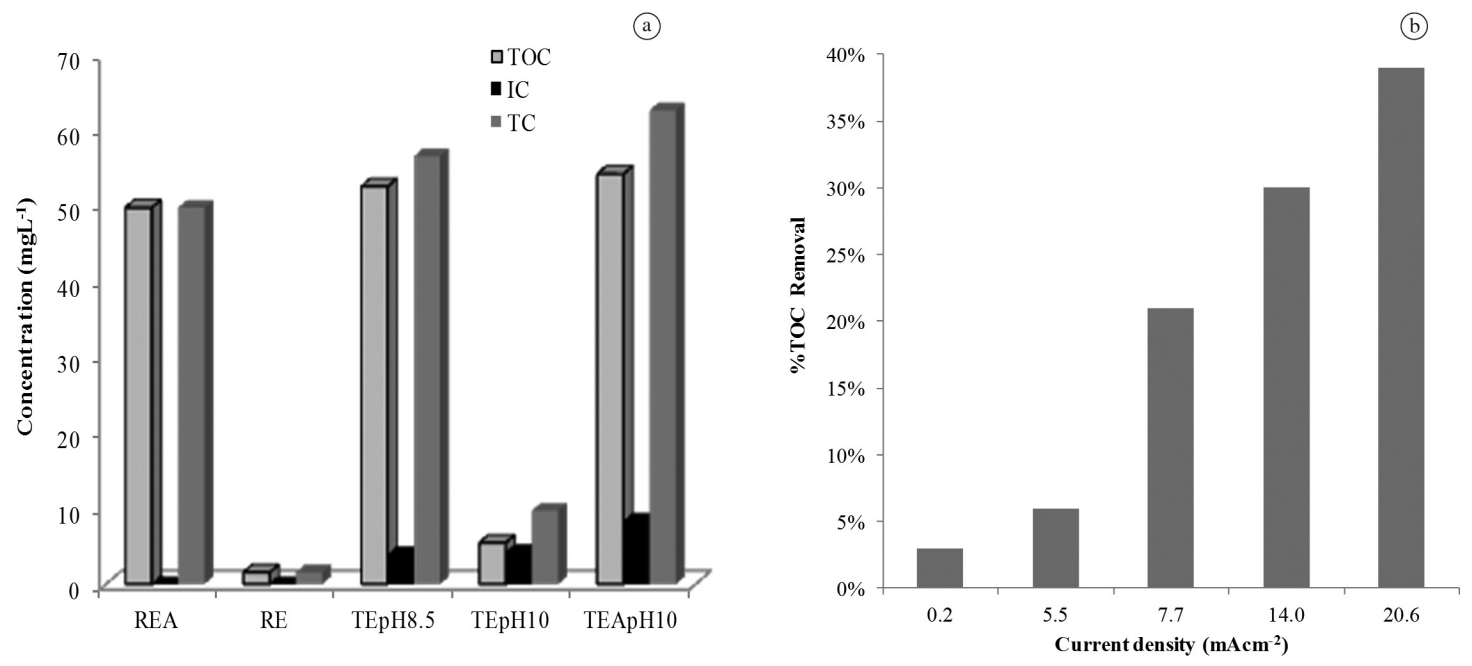

Figure 2. (a) Concentration of carbon species. Experimental values for concentration of inorganic (IC), organic (TOC) and total (TC) carbon in raw and treated solutions, $\mathrm{pH}$ treatment: 8.5 or 10. (b) Total organic carbon degradation. $\mathrm{TOCt}^{\mathrm{TOC}} \mathrm{TO}_{0}$ ratio in the PEO of organic matter as a function of current density to treated samples for sixty minutes. 
The results for D.magna and S.capricornutum for TE and TEA effluents were statistically equal, and were within the range of variability for these tests. The results above confirm that effluent toxicity, even after physical-chemical treatment, requires additional treatment.

\subsection{Effect of current density on photoelectrooxidation}

The treated effluent containing organic additives, TEApH10, was classified as ideal for physico-chemical treatment. It was treated by PEO to degrade organic compounds. In PEO1, $0.2 \mathrm{mAcm}^{-2}$ was applied; and to check the effect of this parameter, $\mathrm{PEO} 2, \mathrm{PEO} 3, \mathrm{PEO} 4$ and PEO5 were performed at 5.5, 7.7, 14 and $20.6 \mathrm{mAcm}^{-2}$ in trials that lasted 60 minutes.

Figure $2 \mathrm{~b}$ shows the effects of current density during PEO. At all current densities, TOC was reduced, and organic matter degradation was 3\% to $38 \%$. These results confirm the positive effect of increased current density for the degradation of organic additives in one-hour tests.

The degradation of organic additives is seen in the spectra of UV-Vis molecular absorption, shown in Figure 3, where bands are identified, and in absorbance reduction after the PEO essays using different current densities. There was a clear difference between sample spectra in function of additives: TEA and REA samples had overlapping and well defined bands in the region of 290 to $250 \mathrm{~nm}$.

Preliminary analyses of individual additive spectra obtained from solutions with the same concentrations found in the raw effluent (REA) indicated that the absorbance for Niv5 $5^{\circledR}$ and Abr $501{ }^{\circledR}$ were reflected in the bands of REA and TEA samples in the 290 to $250 \mathrm{~nm}$ and 240 to $190 \mathrm{~nm}$ ranges. There was no precise information about organic additives composition, except that there was propargyl alcohol and propargyl alcohol ethoxylate in Abr501 ${ }^{\circledR}$ and allyl sodium sulfonate in Niv44 ${ }^{\circledR}$. Silverstein et al. (1991) found that compounds $\left(\mathrm{CH}_{2}\right)_{\mathrm{n}} \mathrm{S}_{2}(\mathrm{n}=[2,5])$ absorb in the 275 to $235-\mathrm{nm}$ wavelength region, and compounds $\left(\mathrm{CH}_{2}\right)_{\mathrm{n}} \mathrm{S}(\mathrm{n}=[3,5])$ absorb at between 333 and $250 \mathrm{~nm}$. This suggests that these molecules may be present in the Abr50 $1^{\circledR}$ and Niv55 ${ }^{\circledR}$ additive formulation. The Niv55 ${ }^{\circledR}$ spectrum was very similar to the one obtained for a $1 \%$ saccharin solution, traditionally used as a leveler additive in nickel electroplating baths (Ciszewski et al., 2004).

The analysis of UV-Vis spectra in Figure 3 confirms the results of TOC in Figure 2b. In PEO1 $\left(\mathrm{i}=0.2 \mathrm{mAcm}^{-2}\right)$, there was a clear reduction of up to $42 \%$ in the absorption band between 270 and $245 \mathrm{~nm}$. A reduction, although less pronounced, also occurs at $240 \mathrm{~nm}$. PEO2 had a very similar behavior $\left(\mathrm{i}=5.5 \mathrm{mAcm}^{-2}\right)$, and there was a $48.72 \%$ band absorption reduction between 270 and $245 \mathrm{~nm}$.

PEO3 and PEO4 essays had the largest absorption reduction across the spectrum, reaching $69.5 \%$ between 270 and $245 \mathrm{~nm}$. When compared with PEO4, the PEO3 test showed that absorption decreased more in the wavelength region below $230 \mathrm{~nm}$; however, both spectra were very distant from the initial level (REA and TEApH10).

The final PEO5 sample, treated with the highest current density, showed a major effect in absorption reduction, which reached $82.4 \%$ between 270 and $245 \mathrm{~nm}$. This was the lowest absorption among the spectra showed in Figure 3. The effect of current density on organic matter removal was confirmed by greater degradation at higher current densities, an effect cited by Pinhedo et al. (2005) in their study of humic acid degradation by electrolysis, and assisting electrolysis with photocatalysis evaluated in the UV-Vis spectrum and TOC. However, high current density implies high energy consumption, which increases treatment cost.

\subsection{Effect of treatment time}

PEO1 $\left(0.2 \mathrm{mAcm}^{-2}\right)$ was evaluated by TOC and UV - Vis absorption for an additional sixty minutes during twelve hours. The behavior of TOC was analysed according to

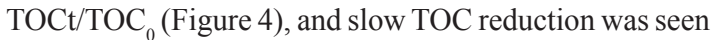
in the early hours of the test. After five hours and until the end of the test, TOC was reduced by $21.2 \%$. This result was the same as the one found for PEO3, in which $7.7 \mathrm{mAcm}^{-2}$ was applied for $60 \mathrm{~min}$ (Figure 2b).

The UV-Vis spectrum in Figure 5 confirms TOC results. The absorption bands decreased between 270 to $245 \mathrm{~nm}$

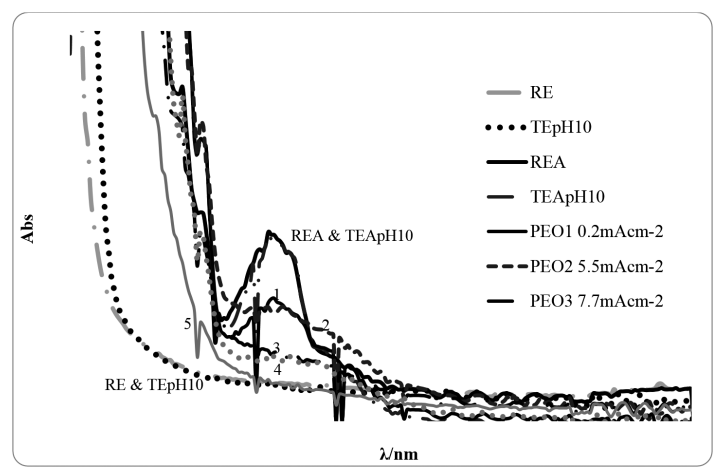

Figure 3. Characteristics of UV-Vis spectra for RE, REA, TEpH10, TEApH10, and for PEO treated samples after 60 minutes at different operating current densities.

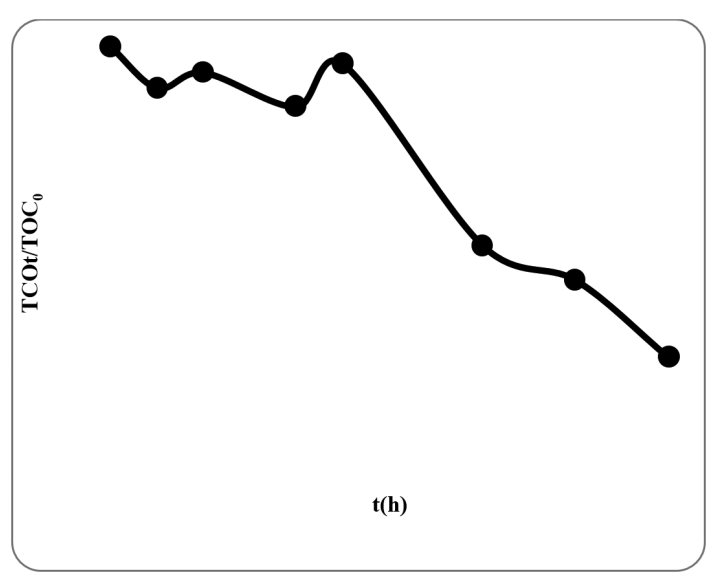

Figure 4. Variation of TOC concentration as a function of treatment time in PEO1 $\left(0.2 \mathrm{mAcm}^{-2}\right)$. 
and from 240 to $200 \mathrm{~nm}$ during the first sixty minutes. In Figure 5, the absorbance reduction at $258 \mathrm{~nm}$ was $49.1 \%$, similar to that of $\mathrm{PEO} 2$, under $\mathrm{i}=5.5 \mathrm{mAcm}^{-2}$ for sixty minutes (Figure 2b).

Longer experiments showed the effectiveness in the degradation of organic compounds, even at low current densities, which required only longer treatment times. Also, while it is applying a low electric current, $12 \mathrm{~h}$ tests require further monitoring and control due to the heating of the solution; and, for the application of PEO in the treatment of industrial effluents, space and residence time are critical items for implement new process for wastewater treatment, particularly in the case of a polishing process, increasingly necessary to achieve specific parameters.

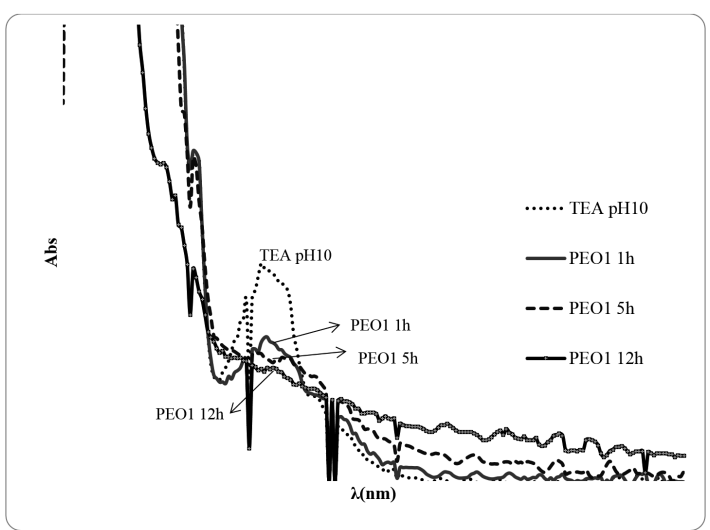

Figure 5. UV-Vis spectra for samples collected during PEO1 test under application of $\mathrm{i}=0.2 \mathrm{mAcm}^{-2}$ current density for twelve hours.

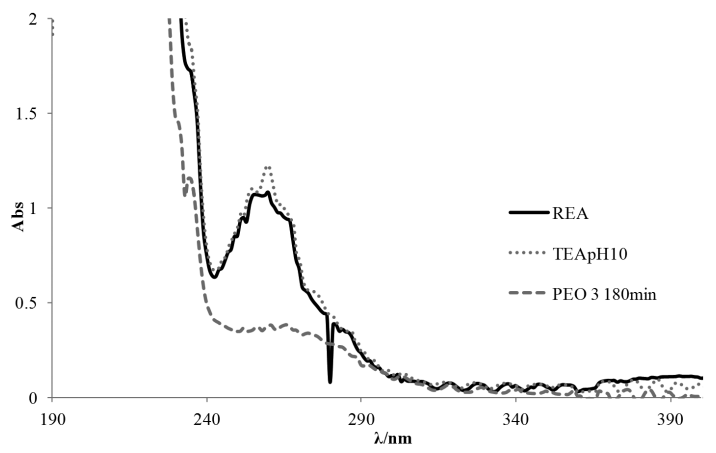

Figure 6. Values of absorption reduction of initial effluents (REA and TEApH10) and after PEO for $180 \mathrm{~min}$ and application at $7.7 \mathrm{mAcm}^{-2}$ (PEO3 $\left.180 \mathrm{~min}\right)$.

\subsection{Effluent toxicity after treatment using PEO}

Incomplete oxidation of organic compounds may result in the formation of more toxic intermediaries and can reduce biodegradability. This is the major limitation of AOPs. During treatment using PEO, TOC removal and reduction of additive absorption confirmed the complete oxidation of organic matter. A new PEO was conducted and submitted to ecotoxicity tests. A median value of current density was selected, $7.7 \mathrm{mAcm}^{-2}$ (used in PEO3), and the treatment was performed for 180 minutes. This test showed a satisfactory response to the increase in treatment time when TOC was evaluated.

The UV-Vis spectrum in Figure 6 shows the reduction of absorption for both initial effluent bands, as in the previous tests. Due of these results, the final sample of PEO3 $180 \mathrm{~min}$, in which $\mathrm{pH} 8.86$ was adjusted to $\mathrm{pH} 7$, was sent for toxicity analysis for the two most sensitive trophic levels to initial REA and TEA solutions: microcrustaceans and algae.

Results are shown in Table 4. There were no changes in the toxicity test with microcrustaceans, showing that nickel concentration was still high and there was no formation of more toxic by-products at a sufficient concentration to change the effect on D.magna. In the same analysis, it was also possible to evaluate the toxicity factor (TF), which indicated that the sample dilution factor did not affect $50 \%$ of organisms for D. Magna. TF did not change after PEO3 $180 \mathrm{~min}$.

The assessment of the toxicity test for algae revealed that PEO treatment not only reduced the concentration of organic matter (TOC and UV-Vis spectrometry analysis), but also led to reduced toxicity for algae, increasing the inhibition concentration, IC(I) 50 , from $4.57 \%$ to $37.25 \%$ after PEO3 180min. TF also confirmed treatment success, as the toxic effect was reduced.

Results were satisfactory because there was no increase in effluent toxicity after PEO for the test organisms under evaluation. Yeber et al. (1999) evaluated different AOPs for pulp mill bleaching wastewater and found that PEO was efficient in reducing TOC and acute toxicity when using Microtox ${ }^{\circledR}$ test for the effluent.

The results of this study revealed that degradation products from organic additives are as toxic as the initial compounds (for microcrustaceans) or less toxic than initial compounds. However, residual nickel concentrations may still cause toxicity. This was confirmed in the toxicity test with algae, wherein the degradation of organic matter reduced the effluent toxicity to $S$. capricornutum

Table 4. Ecotoxicity results for TEApH10 and PEO3 $\left(7.7 \mathrm{mAcm}^{-2}, 180 \mathrm{~min}\right)$ samples.

\begin{tabular}{|c|c|c|c|c|}
\hline \multirow{3}{*}{ Sample } & \multicolumn{4}{|c|}{ Acute toxicity } \\
\hline & \multicolumn{2}{|c|}{ Daphnia magna } & \multicolumn{2}{|c|}{ Selenastrum capricornutum } \\
\hline & $\mathbf{T F}^{\mathbf{a}}$ & EC(I)50, 48h & TF & IC(I)50, 72h \\
\hline TEApH10 & 2 & $70.71 \%$ & 64 & $4.57 \%$ \\
\hline PEO3 $\left(7.7 \mathrm{mAcm}^{-2}, 180 \mathrm{~min}\right)$ & 2 & $70.71 \%$ & 8 & $37.25 \%$ \\
\hline
\end{tabular}

${ }^{a} \mathrm{TF}$ : toxicity factor (sample dilution factor does not affect $50 \%$ of organisms). 


\section{Conclusions}

After conventional treatment, was confirmed the difficulty in reaching the standard for treated effluent disposal in relation to the concentration of nickel, as TOC did not remove, but increased. Study techniques that degrade organic compounds should be investigated, which opens up the possibility of using an AOP, such as PEO.

When higher current densities were applied, there was a greater reduction of TOC and UV-Vis spectra absorption of test samples in the first sixty minutes. The longest experiments showed the highest rates of degradation, but further studies about efficiency and energy consumption should be performed to determine parameters as a function of the volume of the effluent to be treated.

These results confirm the success of the PEO technique to degrade organic additives. The intermediaries generated during degradation were less toxic for S. capricornutum and did not change TF for microcrustaceans. Before this study, solutions treated using PEO were not within the toxicity limits required for disposal. Studies to optimise parameters may determine the final quality of treated effluents and reduce environmental impacts of the disposal of these compounds, surfactants and a wide variety of unidentified compounds that increase pollution in the Sinos River basin.

\section{Acknowledgements}

The authors thank CAPES, CNPq, FAPERGS and FINEP for their financial support.

\section{References}

ALLEN, HE., CHEN, P-H., 1993. Remediation of metal contaminated soil by EDTA incorporating electrochemical recovery of metal and EDTA. Environmental Progress,vol. 12, no. 4, p. 284-293.

American Society for Testing and Materials - ASTM, 1987. E 1193: Standard guide for conducting renewal life-cycle toxicity tests with D. magna. In American Society for Testing and Materials (Ed.). Annual book of ASTM standards. Philadelphia: ASTM. p. 765-781.

Associação Brasileira de Norma Técnicas - ABNT, 2004. NBR 15.088: Ecotoxicologia aquática - Toxicidade Aguda-Método de ensaio com peixes. Rio de Janeiro: ABNT. 19 p.

Associação Brasileira de Norma Técnicas - ABNT, 2005. NBR 12.648: Ecotoxicologia aquática - Toxicidade Crônica-Método de ensaio com algas (Chlorophyceae). Rio de Janeiro: ABNT. 24 p.

Associação Brasileira de Norma Técnicas - ABNT, 2009. NBR 12.713: Ecotoxicologia aquática - Toxicidade aguda - Método de ensaio com Daphnia ssp (Crustacea, Cladocera). Rio de Janeiro: ABNT. 23 p.

BENVENUTI, T., HAUBERT. G., BERNARDES, AM., FERREIRA, JZ. 2011. Photoelectrooxidation applied to the treatment of nickel electroplating effluent for degrade organic compounds. In Anais do XVII Simpósio Brasileiro de Eletroquímica e Eletroanalítica. 2011. Bento Gonçalves. Lajeado: Editora Univates. p. 572-575.
BRASIL. Conselho Nacional do Meio Ambiente - CONAMA, 2005. Resolução $n^{\circ} 357$ de 17 de março de 2005. Dispõe sobre a classificação dos corpos de água e diretrizes ambientais para o seu enquadramento, bem como estabelece as condições $e$ padrões de lançamento de efluentes, e dá outras providências. Diário Oficial da União, Brasília, 18 mar., p. 58-63. Avaliable from: $<$ http://www.mma.gov.br/port/conama/res/res05/res35705. pdf $>$. Access in: 12 Nov. 2012.

BRASIL. Ministério do Meio Ambiente-MMA, Agência Nacional das Águas-ANA, 2007. GEO Brasil recursos hídricos. Componente da série de relatórios sobre o estado e perspectivas do meio ambiente no Brasil. Brasília: MMA/ANA. 264 p.

CAMPBELL, DA., DALRYMPLE, IM., SUNDERLAND, JG. and TILSTON, D., 1994. The electrochemical recovery of metals from effluent and process streams. Resources, Conservation and Recycling, vol. 10, no. 1-2, p. 25-33. http://dx.doi.org/10.1016/09213449(94)90035-3.

CISZEWSKI, A., POSLUSZNY, S., MILCZAREK, G. and BARANIAK, M., 2004. Effects of saccharin and quaternary ammonium chlorides on the electrodeposition of nickel from a Watts-type electrolyte. Surface and Coatings Technology, vol. 183, no. 2-3, p. 127-133. http://dx.doi.org/10.1016/j.surfcoat.2003.09.054.

FU, F. and WANG, Q., 2011. Removal of heavy metal ions from wastewaters: a review. Journal of Environmental Management, vol. 92, no. 3, p. 407-418. http://dx.doi.org/10.1016/j.jenvman.2010.11.011. PMid:21138785.

KANG, SF., CHEN, HW., WANG, GS., 2001. Catalyzed UV oxidation of organic pollutants in biological treated wastewater effluents. The Science of the Total Environment, vol. 277, p. 87-94.

LU, AL., MA, Y-S., KUMAR, M. and LIN, J-G., 2011. PhotoFenton pretreatment of carbofuran - analyses via experimental design, detoxification and biodegradability enhancement. Separation and Purification Technology, vol. 81, no. 3, p. 325-331. http:// dx.doi.org/10.1016/j.seppur.2011.07.040.

MANU, B. and MAHAMOOD, S., 2011. Enhanced degradation of paracetamol by UV-C supported photo-Fenton process over Fenton oxidation. Water Science and Technology : a Journal of the International Association on Water Pollution Research, vol. 64, no. 12, p. 2433-2438. http://dx.doi.org/10.2166/wst.2011.804. PMid:22170838.

MASZENAN, AM., LIU, Y. and NG, WJ., 2011. Bioremediation of wastewaters with recalcitrant organic compounds and metals by aerobic granules. Biotechnology Advances, vol. 29, no. 1, p. 111-123. http://dx.doi.org/10.1016/j.biotechadv.2010.09.004. PMid:20940035.

PINHEDO, L., PELEGRINI, R., BERTAZZOLI, R., MOTHEO, AJ., 2005. Photoelectrochemical degradation of humic acid on a ( $\mathrm{TiO} 2) 0.7(\mathrm{RuO} 2) 0.3$ dimensionally stable anode. AppliedCatalisys. B. Environment, vol. 57, no. 2, p. 75-81.

Rio Grande do Sul. Secretaria Estadual do Meio Ambiente do Rio Grande do Sul - SEMA, Fundação Estadual de Proteção Ambiental Henrique Luis Roessler - FEPAM, 2001. Diagnóstico da Poluição Hídrica na Região Hidrográfica do Guaíba. Available from: $<$ http://www.fepam.rs.gov.br/biblioteca/diagrguaiba.asp $>$. Access in: 10 Dez. 2012.

Rio Grande do Sul. Secretaria Estadual do Meio Ambiente do Rio Grande do Sul - SEMA, Conselho Estadual do Meio Ambiente CONSEMA, 2006. Resolução 129, de 24 de novembro de 2006. Dispõe sobre a definição de Critérios e Padrões de Emissão para Toxicidade de Efluentes Líquidos lançados em águas superficiai 
do estado do Rio Grande do Sul. Diário Oficial do Estado, Porto Alegre, 7 dec. Available from: <http://www.sema.rs.gov.br/ conteudo.asp?cod_menu=216\&cod_conteudo $=7207 \&$ busca $=129>$. Access in: 12 Nov. 2012.

RODRIGUES, MAS., AMADO, FDR., XAVIER, JLN., STREIT, KF., BERNARDES, AM. and ZOPPAS-FERREIRA, J., 2008. Application of photoelectrochemical-electrodialysis treatment for the recovery and reuse of water from tannery effluents. Journal of Cleaner Production, vol. 16, no. 5, p. 605-611. http://dx.doi. org/10.1016/j.jclepro.2007.02.002.

SCHARIO, M., 2007. Troubleshooting decorative nickel plating solutions (Part I of III installments): any experimentation involving nickel concentration must take into account several variables, namely the temperature, agitation, and the nickel-chloride mix. Metal Finishing, vol. 105, no. 4, p. 34-36. http://dx.doi.org/10.1016/ S0026-0576(07)80584-8.

SILVERSTEIN, RM. and BASSLER, GC., MORRIL, TC., 1991. Spectrometric identification of organic compounds. 5 th ed. New York: John Wiley \& Sons.

United States of American. United States Environmental Protection Agency - USEPA, 2002a. Pimephales promelas, acute toxicity tests with effluents and receiving Waters (Test Method 2000.0). In United States of American (Ed.). Methods for Measuring the Acute Toxicity of Effluents and Receiving Waters to Freshwater and Marine Organisms. 5th ed. Washington: U.S. Environmental Protection Agency.

United States of American. United States Environmental Protection Agency - USEPA, 2002b. Green Algae, Selenastrum capricornutum, Growth Test Method 1003.0. In United States of American (Ed.). Short-term Methods for Estimating the Chronic Toxicity of Effluents and Receiving Waters to Freshwater Organisms. 4th ed. Washington: U.S. Environmental Protection Agency.

VENUGOPALAN, VP., NANCHARAIAH, YV., MOHAN, TVK., NARASIMHAN, SV., 2005. Biogranulation: self-immobilised microbial consortia for high performance liquid waste remediation. BARC Newslatter, vol. 254, p. 1-8.

YAN-YANG, C., LING-LING, L. and MAO-JUAN, B., 2011. Dual-electrode oxidation used for aniline degradation in aqueous electrolyte. Water Science and Technology : a Journal of the International Association on Water Pollution Research, vol. 63, no. 11, p. 2583-2589. http://dx.doi.org/10.2166/wst.2011.567. PMid:22049752.

YEBER, MC., RODRÍGUEZ, J., FREER, J., BAEZA, J., DURÁN, N. and MANSILLA, HD., 1999. Advanced oxidation of a pulp mill bleaching wastewater. Chemosphere, vol. 39, no. 10, p. 1679-1688. http://dx.doi.org/10.1016/S0045-6535(99)00068-5. PMid:10520485. 